\title{
The effect of a chemical additive on the fermentation and aerobic stability of high-moisture corn
}

\author{
T. C. Da Silva, ${ }^{*}$ M. L. Smith, $\dagger$ A. M. Barnard, $\dagger$ and L. Kung Jr. $\dagger^{1}$ \\ *Federal University of Vicosa, Minas Gerais, Brazil 36570000 \\ †Department of Animal and Food Sciences, University of Delaware, Newark 19716
}

\begin{abstract}
The objective of this experiment was to evaluate the effect of a chemical additive on the fermentation and aerobic stability of high-moisture corn (HMC). Ground HMC ( $\sim 63 \%$ dry matter) was untreated, or treated with an additive containing sodium benzoate, potassium sorbate, and sodium nitrite as active ingredients, at $0,2,3$, or $4 \mathrm{~L} / \mathrm{t}$ of fresh matter. Laboratory silos $(7.5 \mathrm{~L})$ were prepared and ensiled for 21 and $90 \mathrm{~d}(4$ silos/treatment per d of ensiling). Small bag silos were prepared for untreated HMC and HMC treated with $4 \mathrm{~L} / \mathrm{t}$ of the additive and analyzed for nitrate- $\mathrm{N}$ and nitrite- $\mathrm{N}$ after 0,3 , and $7 \mathrm{~d}$ of ensiling. The concentration of nitrate- $\mathrm{N}$ was similar between these 2 treatments and was below levels considered problematic for ruminants. Nitrite-N was greater in HMC treated with the high level of additive but was also very low for both treatments. Numbers of yeasts were similar among treatments in fresh HMC and decreased substantially after ensiling. Numbers of yeasts were similar among treatments after $21 \mathrm{~d}$ of ensiling but after $90 \mathrm{~d}$ they were lower in treated versus untreated HMC. Concentrations of organic acids (lactic, acetic, and propionic) and $\mathrm{pH}$ were not different among treatments at any time of ensiling. In contrast, treatment with the additive markedly decreased the concentration of ethanol in HMC after 21 and $90 \mathrm{~d}$ when compared with untreated HMC. Treatment with all levels of the additive markedly improved the aerobic stability and improved the recovery of dry matter compared with untreated HMC. Overall, our findings suggest that the chemical additive used in this study has the potential to improve the fermentation and aerobic stability of HMC after a relatively short period $(21 \mathrm{~d})$ and after a moderate length (90 d) of ensiling.
\end{abstract}

Key words: silage, potassium sorbate, sodium benzoate, yeast

Received March 27, 2015.

Accepted August 14, 2015.

${ }^{1}$ Corresponding author: lksilage@udel.edu

\section{INTRODUCTION}

High-moisture corn (HMC) is commonly fed to animals throughout the world (Buchanan-Smith et al., 2003; Szasz et al., 2007; Canizares et al., 2011). However, this ensiled feedstuff often has a high number of epiphytic yeasts (3-5 log cfu/g, Pahlow et al., 2003) and its aerobic stability can be very poor, especially when ambient temperatures are warm (Taylor and Kung, 2002; Kung et al., 2004). The reasons why HMC is high in yeasts is not clearly understood, but may be related to the fact that the plant is shuttling sugars to the ear and any potential physical damage to the ear results in potential substrate for these organisms (Teller et al., 2012). The aerobic deterioration of ensiled feeds results in a loss of DM and an increase in the numbers of undesirable microorganisms (Lindgren et al., 2002; Borreani et al., 2013), which may produce toxic substances harmful to animals and humans (Ivanek et al., 2006; Alonso et al., 2013). In addition, feeding aerobically spoiled silages can result in depressions in nutrient intake (Whitlock et al., 2000; Gerlach et al., 2013) and production (Hoffman and Ocker, 1997) in ruminants.

Because lactate-assimilating yeasts are usually thought to initiate aerobic spoilage in ensiled feeds, additives containing or generating antifungal components have been used to decrease their numbers to improve aerobic stability. For example, microbial-based additives such as Lactobacillus buchneri can convert lactic acid to acetic acid, which has good antifungal attributes (Taylor and Kung, 2002). However, one drawback of using this microbe is that it has a slow growth rate (Schmidt et al., 2009) and its effects often requires about 50 to $60 \mathrm{~d}$ (or longer) of ensiling to be detected in corn silage (Kleinschmit et al., 2005) and HMC (Taylor and Kung, 2002). Chemical-based additives with antifungal properties such as various organic acids (Yasin et al., 1992; Sebastian et al., 1996) or ammonia (Diaz et al., 2013) have also been successful in improving the aerobic stability of HMC. These additives are not dependent on the growth of added microorganisms for their antifungal effects. An additive based on sodium benzoate, potassium sorbate, and sodium nitrite has 
recently been evaluated in forage-based ensiled crops (Knický and Spörndly, 2011) and HMC (Loučka, 2010), but to our best knowledge no peer-reviewed publications were available on this formulation in North America when the current research was undertaken. Thus, the objective of this study was to evaluate several doses of this additive on the fermentation characteristics and aerobic stability of ensiled HMC after different lengths of storage.

\section{MATERIALS AND METHODS}

\section{Ensiling of HMC and Treatments}

Shelled corn (unknown hybrid), from a commercial dairy farm, was harvested with a John Deere 9400 combine (Moline, IL) at about $63 \% \mathrm{DM}$ and ground through a Gehl hammer mill (model \#170, Manitou Americas Inc., West Bend, WI). Freshly ground HMC was transported to the University of Delaware where it was treated within $2 \mathrm{~h}$ of harvest with (1) control, no additive; (2) 2.0 L of Safesil (Ab Hanson and Möhring, Halmstad, Sweden)/t of fresh matter, S2; (3) $3.0 \mathrm{~L}$ of Safesil/t, S3; or (4) $4.0 \mathrm{~L}$ of Safesil/t, S4. The active ingredients in the additive were sodium benzoate $(200$ $\mathrm{g} / \mathrm{kg})$, potassium sorbate $(100 \mathrm{~g} / \mathrm{kg})$, and sodium nitrite $(50 \mathrm{~g} / \mathrm{kg}$ ). Four replicated piles (each pile treated individually) containing $20 \pm 0.03 \mathrm{~kg}$ of ground HMC were prepared for each treatment (total of 16 piles). Each pile was treated with a volume of $200 \mathrm{~mL}$ of liquid to ensure uniform treatment distribution (water alone for the no additive treatment or water mixed with appropriate amounts of the additive to obtain the targeted application rate). Treatments were applied with a hand sprayer while manually mixing the HMC.

High-moisture corn from each pile was packed in 7.5$\mathrm{L}$ bucket silos and sealed with plastic lids with O-ring seals. Targeted packing density was approximately 672 $\pm 5 \mathrm{~kg}$ of $\mathrm{DM} / \mathrm{m}^{3}$. Buckets were stored for 21 and 90 $\mathrm{d}$ at $22^{\circ} \mathrm{C}$ before opening. Weights of full and empty bucket silos were recorded at the start and at each opening. Dry matter recovery was determined based on the differences between weights at ensiling and at the openings according to Jobim et al. (2007).

Three bag silos containing approximately $600 \mathrm{~g}$ of $\mathrm{HMC}$ were also prepared from each of the replicate piles 1 to 3 for each of the no additive and S4 treatments. The bag silos were made of nylon-polyethylene (3.5-mil embossed pouches, $15.2 \times 30.5 \mathrm{~cm}$; Doug Care Equipment Inc., Springville, CA). Air was evacuated from the bags before they were heat-sealed using a Best Vac vacuum machine (distributed by Doug Care Equipment Inc.). Bag silos were opened after 3 and $7 \mathrm{~d}$ of ensiling. All silos (buckets and bags) were stored at $22^{\circ} \mathrm{C}$.
The aerobic stability of HMC was determined at each silo opening for samples from the bucket silos. At each opening, approximately $2 \pm 0.01 \mathrm{~kg}$ of representative HMC from each bucket silo was returned to the same cleaned silo without compaction. A thermocouple wire was placed in the geometric center of each sample mass and temperatures were recorded every 15 min using a data logger DataTaker DT85 (Thermo Fisher Scientific Australia Pty, Scoresby, VIC, Australia). Ambient temperature was recorded from a thermocouple wire in an empty bucket. Buckets were covered with 2 layers of cheesecloth and exposed to air in the laboratory (22 $\pm 1^{\circ} \mathrm{C}$ ). Aerobic stability was calculated as the number of hours before the temperature of the silage mass rose $2^{\circ} \mathrm{C}$ above baseline temperature.

\section{Laboratory Analyses}

Fresh HMC before ensiling from each pile was sampled and analyzed for DM, NDF, ADF, CP, soluble protein (SP), starch, pH, lactic acid bacteria (LAB), yeasts and molds, $\mathrm{NH}_{3}-\mathrm{N}$, water-soluble carbohydrates (WSC), and buffering capacity. The DM content of the samples (approximately $150 \mathrm{~g}$ ) was determined in a $60^{\circ} \mathrm{C}$ forced-air oven for $48 \mathrm{~h}$. A portion of each dried sample was ground using an Udy Cyclone Sample Mill (Udy Corp., Fort Collins, CO) to pass through a 1-mm screen and analyzed for NDF via the procedures of Van Soest et al. (1991). Acid detergent fiber was quantified on dried ground samples according to procedures described by Goering and Van Soest (1970), with the modification that the fiber residue from the ADF was recovered on a $1.5-\mu \mathrm{m}$ particle retention $7-\mathrm{cm}$ Whatman filter in a California Buchner Funnel (934$\mathrm{AH}$, Whatman Inc., Clifton, NJ) instead of a Gooch crucible, to allow for better filtration. Total $\mathrm{N}$ was determined by combustion of the sample (Leco CNS 2000 Analyzer, Leco Corporation, St. Joseph, MI), and $\mathrm{CP}$ was calculated by multiplying the resulting total $\mathrm{N}$ by 6.25 . Soluble protein (\% of CP) was determined by the method of Krishnamoorthy et al. (1982). A separate portion of the dried samples was ground to pass through a 3-mm screen and analyzed for starch (Hall, 2009). Dried samples from the bag silos were analyzed for concentrations of nitrate- $\mathrm{N}$ and nitrite- $\mathrm{N}$ at the Swedish University of Agricultural Sciences, Uppsala, Sweden as described by Knický and Spörndly (2009) using the ASN 110-01/92 method (Tecator, 1992) with a FIA system from FOSS-Tecator (Höganäs, Sweden).

Representative samples of fresh and ensiled HMC were mixed with sterile quarter strength Ringer's solution (Oxoid BR0052G, Oxoid, Unipath Ltd., Basingstoke, UK) and homogenized for $1 \mathrm{~min}$ in a ProctorSilex 57171 blender (Hamilton Beach/Proctor-Silex 
Inc., Washington, NC). The homogenates were filtered through 4 layers of cheesecloth and a Whatman 54 filter paper (Whatman Inc.). The $\mathrm{pH}$ and microbial populations were determined on fresh water extracts. The numbers of LAB were determined by pour-plating 10-fold serial dilutions on de Man, Rogosa, and Sharpe agar (CM3651, Oxoid). Plates were incubated aerobically at $32^{\circ} \mathrm{C}$ for 48 to $72 \mathrm{~h}$. Yeasts and molds were determined by pour-plating 10 -fold serial dilutions of malt extract agar (CM0059, Oxoid) that, after autoclaving, had been acidified with $0.5 \%$ (vol/vol) lactic acid $(85 \%$ purity). These plates were also incubated at $32^{\circ} \mathrm{C}$ for 48 to $72 \mathrm{~h}$ before enumeration. Portions of the water extracts were frozen and later analyzed for lactic, acetic, propionic, and butyric acids and ethanol (Muck and Dickerson, 1988) with a Shimadzu LC-20AD HPLC (Shimadzu Scientific Instruments, Columbia, $\mathrm{MD}$ ). The concentration of $\mathrm{NH}_{3}-\mathrm{N}$ was determined on the water extracts by a phenol-hypochlorite method of Weatherburn (1967). The WSC were quantified by a colorimetric procedure (Nelson, 1944). The buffering capacity was determined in the fresh samples, according to Playne and McDonald (1966).

\section{Experimental Design and Statistical Analysis}

The data from d 0 opening were analyzed separately as a completely randomized design, including the fixed effect of additive treatment in the model. Data from the silo openings were analyzed as a $2 \times 4$ factorial arrangement of treatments in a completely randomized design, with 4 replicates per treatment. The model in- cluded the fixed effects of the additive, days of ensiling, and their interaction. Data were analyzed using the PROC GLM of the software SAS 9.3 (SAS Institute Inc., Cary, NC), and differences were reported as significant when $P \leq 0.05$. When the overall $P$-value was significant, means were separated by Tukey's test $(P$ $\leq 0.05$; Snedecor and Cochran, 1980). The slice option was used when the effect of interaction was significant to study the levels of additive within each day of ensiling and to study the effect of day of ensiling within each level of the additive.

\section{RESULTS AND DISCUSSION}

\section{Chemical Composition and Microbial Populations of Fresh HMC}

The chemical composition and $\mathrm{pH}$ of HMC (Table 1) were similar for all treatments before ensiling and were typical of this feedstuff (Ferraretto et al., 2014) with the exception of a low concentration of $\mathrm{CP}$, which may have been the result of inadequate amounts of $\mathrm{N}$ fertilization. For microbial populations, the numbers of LAB varied among treatments, but these differences were biologically small. The average number of yeasts in the fresh HMC was $6.93 \mathrm{log} \mathrm{cfu} / \mathrm{g}$ and did not differ among treatments. Molds (data not shown) were detected only in the untreated, fresh HMC, with an average of $4.42 \mathrm{log} \mathrm{cfu} / \mathrm{g}$ and were below the lowest dilution $\left(10^{-2}\right)$ used in this study for other treatments, suggesting some immediate effect of the additive on these organisms.

Table 1. The DM content, chemical composition (\% of DM, unless stated otherwise), pH, microbial composition (fresh weight basis), and buffering capacity ( $\mathrm{mEq} \mathrm{NaOH} / 100 \mathrm{~g}$ of $\mathrm{DM}$ ) of fresh high-moisture corn treated with a chemical additive before ensiling

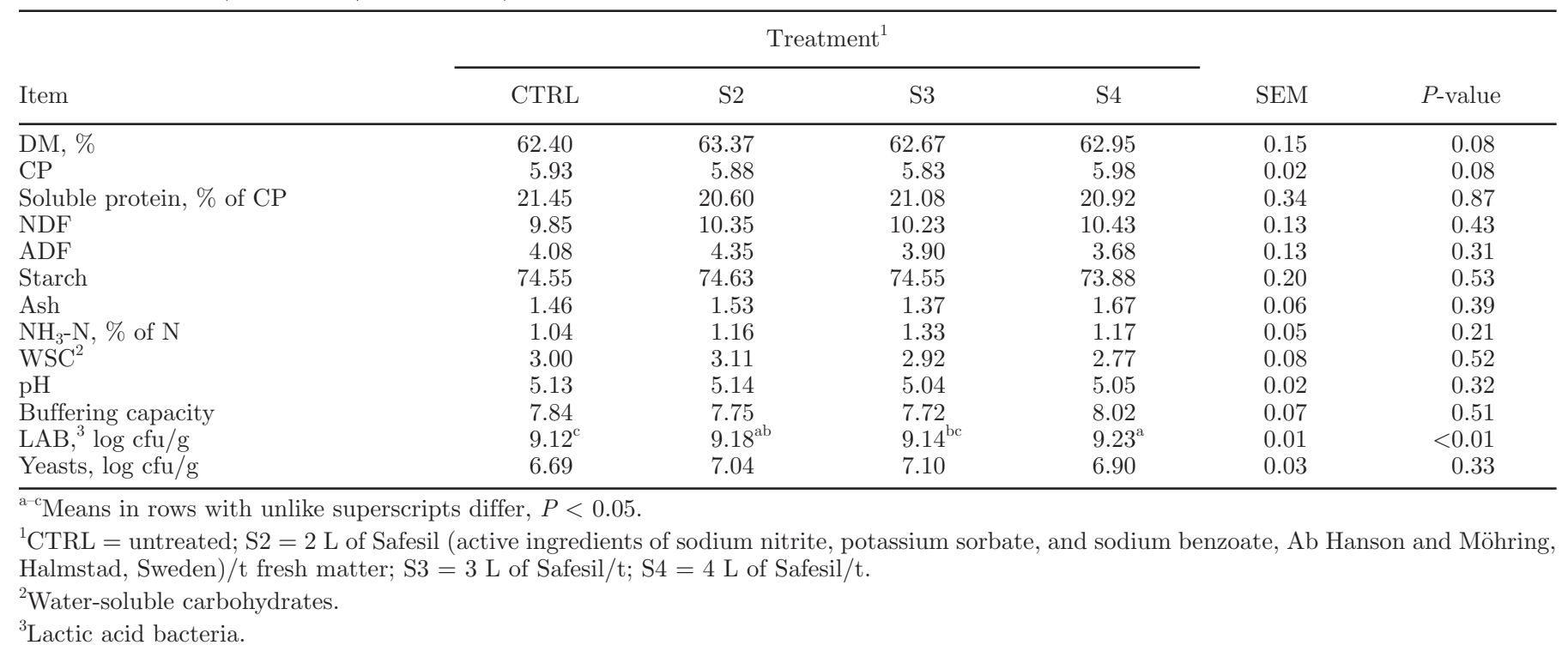


Table 2. The concentrations of nitrate and nitrite $\left(\mathrm{mg} / \mathrm{kg}\right.$ of DM) of high-moisture corn silage treated with no additive $(\mathrm{CTRL})$ or with Safesil $^{1}$ at $4 \mathrm{~L} / \mathrm{t}$ of fresh matter (S4) after 3 and $7 \mathrm{~d}$ of ensiling

\begin{tabular}{|c|c|c|c|c|c|c|c|}
\hline \multirow[b]{2}{*}{ Item } & \multicolumn{2}{|c|}{ Treatment } & \multirow[b]{2}{*}{ Mean } & \multirow[b]{2}{*}{ SEM } & \multicolumn{3}{|c|}{$P$-value ${ }^{2}$} \\
\hline & CTRL & S4 & & & SFE & Day & $\mathrm{SFE} \times$ day \\
\hline d 0 & 4.35 & 7.91 & 6.13 & & & & \\
\hline d 3 & 5.15 & 5.39 & 5.27 & & & & \\
\hline d 7 & 9.29 & 8.27 & 8.78 & & & & \\
\hline Mean & 6.23 & 7.19 & & & & & \\
\hline d 3 & 0.68 & 1.00 & $0.84^{\mathrm{B}}$ & & & & \\
\hline d 7 & 0.68 & 1.00 & $0.84^{\mathrm{B}}$ & & & & \\
\hline Mean & $0.81^{\mathrm{b}}$ & $1.25^{\mathrm{a}}$ & & & & & \\
\hline
\end{tabular}

$\overline{\mathrm{A}, \mathrm{B}, \mathrm{a}, \mathrm{b}}$ Means with different uppercase letters within a column and lowercase letters within a row differ, $P<0.05$.

${ }^{1}$ Active ingredients of sodium nitrite, potassium sorbate, and sodium benzoate, Ab Hanson and Möhring, Halmstad, Sweden)/t of fresh matter. ${ }^{2} \mathrm{SFE}=$ effect of treatment with Safesil; Day $=$ effect of day of ensiling; SFE $\times$ day $=$ interaction between treatment with SFE and day.

\section{Nitrate and Nitrite in Fresh and Ensiled HMC}

The additive evaluated in this study contained active ingredients of sodium benzoate, potassium sorbate, and sodium nitrite. Sodium nitrite is a component of this additive because it has been shown to inhibit clostridia, probably via inactivation of iron-binding enzymes (Woods et al., 1981; Reddy et al., 1983), and thus could be beneficial especially in wet silages with high buffering capacities where these organisms are known to thrive. Potassium sorbate and sodium benzoate are known antifungal compounds that have been used to improve the aerobic stability of silages (Kleinschmit et al., 2005).

In HMC, growth of clostridia would be highly unlikely because of the high osmotic pressure. However, because high levels of nitrates, nitrites, or both, in the rumen have the potential to cause toxicity, we determined the concentrations of these compounds in the untreated and in the S4 treatments after 0,3 , and $7 \mathrm{~d}$ of fermentation (Table 2). Concentrations of nitrate-N were not different among treatments and time of storage. Concentrations of nitrite- $\mathrm{N}$ were affected only by the additive and day of ensiling. Fresh HMC had the highest concentrations of nitrite-N compared with ensiled HMC at 3 and $7 \mathrm{~d}$ of ensiling, which were similar. The HMC treated with S4 had higher concentration of nitrite- $\mathrm{N}$ than untreated HMC. Values in the literature for nitrate- $\mathrm{N}$ and nitrite- $\mathrm{N}$ in HMC were difficult to find, but in a recent access of a database with nutrient composition of corn silages composed of 3,154 samples, nitrate- $\mathrm{N}$ ranged from 0 to $346 \mathrm{mg} / \mathrm{kg}$ with an average value of $92 \mathrm{mg} / \mathrm{kg}$ (Dairy One, 2015). Importantly, levels of nitrate- $\mathrm{N}$ and nitrite- $\mathrm{N}$ in our study were always markedly lower than levels cited as being problematic for ruminants $(>1,000 \mathrm{mg} / \mathrm{kg}$, Ensley and Barnhart,
2012), leading us to conclude that the levels used in our study were well within the safe limits for feeding to ruminants.

\section{Chemical Composition of Ensiled HMC}

The nutrient composition of HMC after 21 and 90 $\mathrm{d}$ of ensiling is shown in Table 3. Unless stated, no interactions were present for the measured components. An interaction was found between the addition of Safesil and day of ensiling for the concentration of DM in ensiled HMC; it increased for all treatments between d 21 and 90 except for treatment with S3. However, the differences observed were not likely large enough to result in detectable differences among treatments in fermentation end products. An interaction was found between the additive and day of ensiling for the concentration of $\mathrm{CP}$ because at the $21 \mathrm{~d}$ opening, HMC treated with $\mathrm{S} 4$ had less $\mathrm{CP}$ than did untreated silage (5.6 vs. $6.00 \% \mathrm{DM}$ ), but at the $90 \mathrm{~d}$ opening the concentration of $\mathrm{CP}$ did not differ among the treatments. The reasons for these differences are unclear, but the differences between treatments were relatively small.

As expected, the concentration of SP increased from 21 to $90 \mathrm{~d}$ of ensiling because of proteolysis that occurs during fermentation and storage of silages (Hoffman et al., 2011). Treatment with S4 resulted in a lower concentration of SP than all other treatments for both days of ensiling. An interaction was observed between the amount of additive used and days of ensiling for $\mathrm{NH}_{3}-\mathrm{N}$ with lower values for HMC treated with $\mathrm{S} 3$ and $\mathrm{S} 4$ in comparison with the control at $21 \mathrm{~d}$ of opening. However, at $90 \mathrm{~d}$ of ensiling, the control had the highest concentration of $\mathrm{NH}_{3}-\mathrm{N}$ and the $\mathrm{S} 2$ had the lowest concentration of $\mathrm{NH}_{3}-\mathrm{N}$ among treatments. The concentration of $\mathrm{NH}_{3}-\mathrm{N}$ remained constant over 
Table 3. The DM concentration and chemical composition (\% of DM, unless stated otherwise) of high-moisture corn silage treated with different levels of Safesil after 21 and $90 \mathrm{~d}$ of ensiling

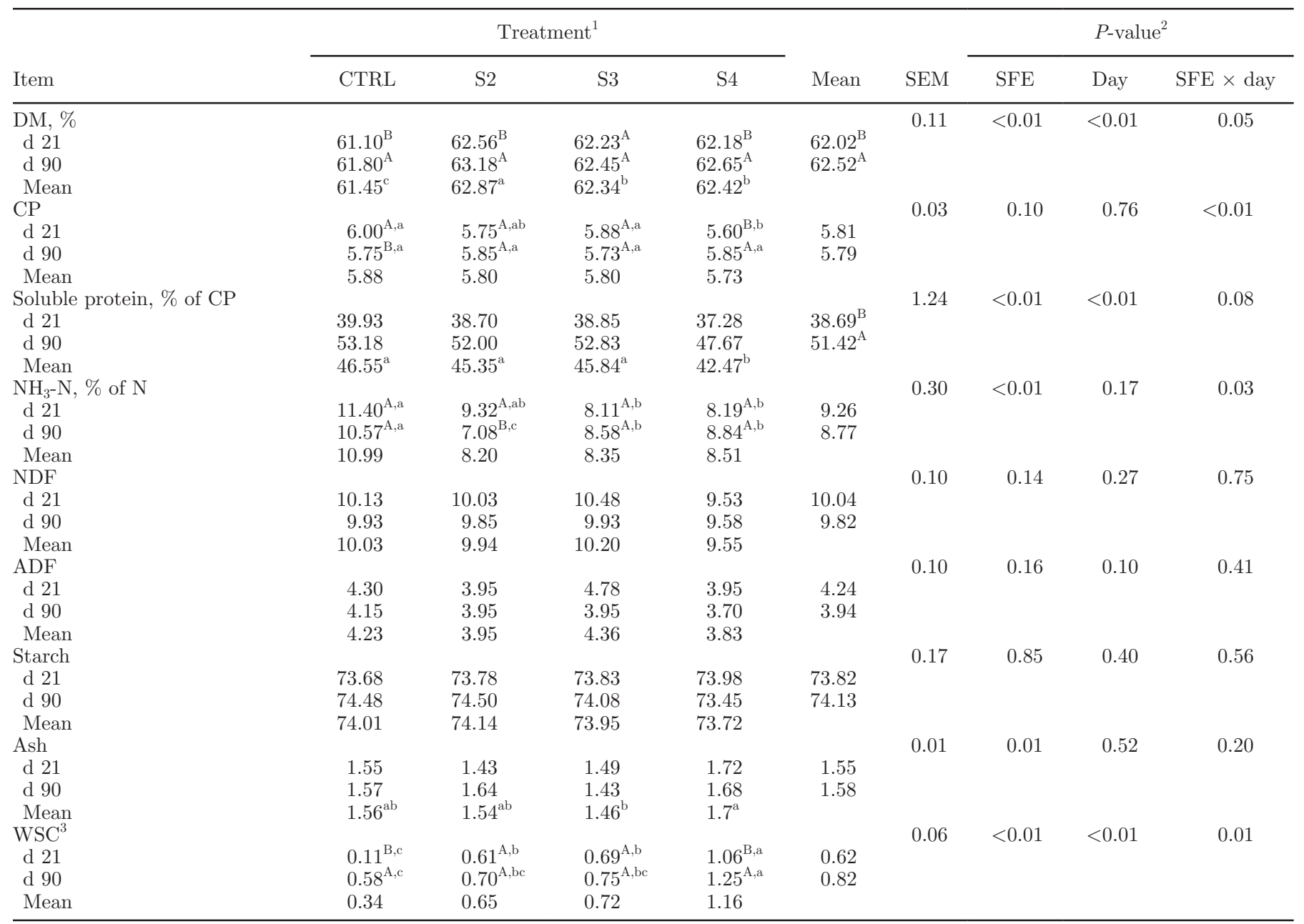

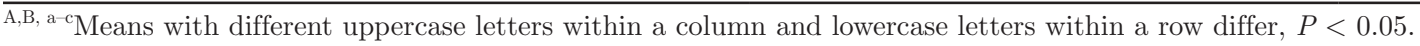

${ }^{1} \mathrm{CTRL}=$ untreated; S2 $=2 \mathrm{~L}$ of Safesil (active ingredients of sodium nitrite, potassium sorbate, and sodium benzoate; Ab Hanson and Möhring, Halmstad, Sweden)/t of fresh matter; S3 $=3 \mathrm{~L}$ of Safesil/t; S4 $=4 \mathrm{~L}$ of Safesil/t.

${ }^{2} \mathrm{SFE}=$ effect of treatment with Safesil; Day $=$ effect of day of ensiling; SFE $\times$ day $=$ interaction between treatment with SFE and day.

${ }^{3}$ Water-soluble carbohydrates.

the days of ensiling, except for the S2-treated HMC, which decreased from 21 to 90 d. Knický and Spörndly (2011) also reported lower concentrations of $\mathrm{NH}_{3}-\mathrm{N}$ in forage crops ensiled with Safesil but attributed those findings to inhibition of clostridia by sodium nitrite. In contrast, concentrations of $\mathrm{NH}_{3}-\mathrm{N}$ were not affected by benzoate or sorbate additions in the studies by Kleinschmit et al. (2005) and Teller et al. (2012), but those studies used corn silages that were not conducive to the growth of clostridia. However, Alli et al. (1985) also reported lower volatile $\mathrm{N}$ in corn and alfalfa silages treated with sorbic acid and potassium sorbate compared with untreated silages. Overall, in our study, consistently lower soluble $\mathrm{N}$ and $\mathrm{NH}_{3}-\mathrm{N}$ for $\mathrm{S} 4$ compared with untreated HMC suggests that the high level of the additive reduced natural proteolytic processes. The concentrations of ADF, NDF, and starch were not affected by Safesil when compared with untreated HMC. The concentration of ash was affected only by Safesil, as it was lower for S3 than S4, although both of these treatments were not different from untreated HMC or S2. An interaction was present between Safesil and day of ensiling for the concentrations of WSC. After $21 \mathrm{~d}$ of ensiling, the concentration of WSC was highest in S4 $(1.05 \%)$, followed by the treatments with S3 and S2, which were not different between each other (0.69 and $0.65 \%$, respectively) but were higher than untreated HMC. However, at the 90-d opening, the concentration of WSC was similar among untreated HMC, S2, and S3, which were all lower than S4. Alli et al. (1985) also 
reported higher WSC in silages treated with sorbic acid and sorbate and suggested that this finding was due to a sparing of fermentable WSC due to the reductions in the number of yeasts. In that study and the current study, bacteria did not make use of the residual WSC to form more acids, and this may have been because of insufficient amounts of metabolic water available for robust microbial growth.

\section{Fermentation and Aerobic Stability of Ensiled HMC}

The fermentation characteristics, microbial composition, DM recovery and aerobic stability of silages after 21 and $90 \mathrm{~d}$ of ensiling are shown in Table 4. An inter- action was found between Safesil and day of ensiling for $\mathrm{pH}$. At $21 \mathrm{~d}$, the HMC treated with S3 and S4 had higher $\mathrm{pH}$ than the control. However, at $90 \mathrm{~d}$, the $\mathrm{pH}$ was similar among the treatments. The $\mathrm{pH}$ of samples was lower, about 3.7, than usual for HMC, but this finding is explainable because our HMC was relatively high in moisture ( $\sim 38 \%)$ for this type of feed. However, a low $\mathrm{pH}$ is beneficial because sorbic and benzoic acids have $\mathrm{p} K_{\mathrm{a}}$ values of 4.74 and 4.20 , respectively, and thus have high proportions of active (undissociated) forms at the $\mathrm{pH}$ found in our samples.

The concentrations of organic acids (lactic, acetic, propionic, and butyric) were similar among all treatments at both times of ensiling. Addition of sodium

Table 4. The $\mathrm{pH}$, fermentation end products (\% of DM, unless stated otherwise), microbial composition (fresh weight basis), DM recovery, and aerobic stability of high-moisture corn silage treated with different levels of Safesil after 21 and 90 d of ensiling

\begin{tabular}{|c|c|c|c|c|c|c|c|c|c|}
\hline \multirow[b]{2}{*}{ Item } & \multicolumn{4}{|c|}{ Treatment $^{1}$} & \multirow[b]{2}{*}{ Mean } & \multirow[b]{2}{*}{ SEM } & \multicolumn{3}{|c|}{$P$-value ${ }^{2}$} \\
\hline & CTRL & $\mathrm{S} 2$ & S3 & $\mathrm{S} 4$ & & & SFE & Day & $\mathrm{SFE} \times$ day \\
\hline d 21 & $3.70^{\mathrm{B}, \mathrm{b}}$ & $3.75^{\mathrm{A}, \mathrm{ab}}$ & $3.77^{\mathrm{A}, \mathrm{a}}$ & $3.76^{\mathrm{A}, \mathrm{a}}$ & 3.74 & \multirow{3}{*}{0.01} & \multirow{3}{*}{0.92} & \multirow{3}{*}{0.01} & \multirow{3}{*}{$<0.01$} \\
\hline d 90 & $3.75^{\mathrm{A}, \mathrm{a}}$ & $3.72^{\mathrm{A}, \mathrm{a}}$ & $3.70^{\mathrm{B}, \mathrm{a}}$ & $3.70^{\mathrm{B}, \mathrm{a}}$ & 3.72 & & & & \\
\hline \multirow{2}{*}{\multicolumn{6}{|c|}{ Lactic acid }} & & & & \\
\hline & & & & & & \multirow[t]{2}{*}{0.04} & \multirow[t]{2}{*}{0.15} & \multirow[t]{2}{*}{0.42} & \multirow[t]{2}{*}{0.69} \\
\hline Mean & 1.63 & 1.48 & 1.39 & 1.57 & & & & & \\
\hline Acetic acid & & & & & & \multirow[t]{4}{*}{0.01} & \multirow[t]{4}{*}{0.19} & \multirow[t]{4}{*}{0.85} & \multirow[t]{4}{*}{0.92} \\
\hline d 21 & 0.34 & 0.38 & 0.41 & 0.37 & 0.37 & & & & \\
\hline d 90 & 0.32 & 0.40 & 0.40 & 0.39 & 0.38 & & & & \\
\hline Mean & 0.33 & 0.39 & 0.40 & 0.38 & & & & & \\
\hline \multirow{2}{*}{ Propionic acid } & & & & & & \multirow[t]{2}{*}{0.01} & \multirow[t]{2}{*}{0.41} & \multirow[t]{2}{*}{0.27} & \multirow[t]{2}{*}{0.62} \\
\hline & 0.09 & 0.09 & 0.09 & 0.08 & 0.09 & & & & \\
\hline Mean & 0.91 & 0.16 & 0.15 & 0.11 & & & & & \\
\hline $\mathrm{LAB},{ }^{3} \log \mathrm{cfu} / \mathrm{g}$ & & & & & & 0.50 & $<0.01$ & $<0.01$ & 0.89 \\
\hline d 21 & 7.93 & 7.69 & 7.61 & 7.53 & $7.69^{\mathrm{A}}$ & & & & \\
\hline d 90 & 2.45 & 2.13 & 2.00 & 2.00 & $2.14^{\mathrm{B}}$ & & & & \\
\hline Mean & $5.19^{\mathrm{a}}$ & $4.91^{\mathrm{b}}$ & $4.80^{\mathrm{b}}$ & $4.77^{\mathrm{b}}$ & & & & & \\
\hline Yeasts, log cfu/g & & & & & & 0.10 & $<0.01$ & $<0.01$ & $<0.01$ \\
\hline d 21 & $3.07^{\mathrm{A}, \mathrm{a}}$ & $3.00^{\mathrm{A}, \mathrm{a}}$ & $3.00^{\mathrm{Aa}}$ & $3.00^{\mathrm{A}, \mathrm{a}}$ & 3.02 & & & & \\
\hline d 90 & $3.22^{\mathrm{A}, \mathrm{a}}$ & $<2.00^{\mathrm{B}, \mathrm{b}}$ & $<2.00^{\mathrm{B}, \mathrm{b}}$ & $<2.00^{\mathrm{B}, \mathrm{b}}$ & 2.30 & & & & \\
\hline Mean & 3.15 & 2.50 & 2.50 & 2.50 & & & & & \\
\hline DM recovery, \% & & & & & & 0.18 & $<0.01$ & $<0.01$ & 0.51 \\
\hline d 21 & 96.60 & 98.53 & 98.75 & 98.61 & $98.12^{\mathrm{B}}$ & & & & \\
\hline d 90 & 97.51 & 99.21 & 99.06 & 99.34 & $98.78^{\mathrm{A}}$ & & & & \\
\hline Mean & $97.05^{\mathrm{b}}$ & $98.87^{\mathrm{a}}$ & $98.90^{\mathrm{a}}$ & $98.97^{\mathrm{a}}$ & & & & & \\
\hline
\end{tabular}

$\overline{\mathrm{A}, \mathrm{B}, \mathrm{a}, \mathrm{b}}$ Means with different uppercase letters within a column and lowercase letters within a row differ, $P<0.05$.

${ }^{1}$ CTRL = untreated; S4 $=4 \mathrm{~L}$ of Safesil (active ingredients of sodium nitrite, potassium sorbate, and sodium benzoate, Ab Hanson and Möhring, Halmstad, Sweden)/t of fresh matter.

${ }^{2} \mathrm{SFE}=$ effect of treatment with Safesil; Day $=$ effect of day of ensiling; SFE $\times$ day $=$ interaction between treatment with SFE and day.

${ }^{3}$ Lactic acid bacteria. 
benzoate or potassium sorbate also did not affect the concentrations of lactic acid in corn silage (Kleinschmit et al., 2005; Teller et al., 2012). The concentration of butyric acid observed in all samples was below the detection limit $(0.03 \% \mathrm{DM})$, and the values are not shown in the tables.

For ethanol, an additive $\times$ day of ensiling interaction occurred because the concentrations declined from $\mathrm{d} 21$ to 90 for untreated corn but remained constant for all Safesil treatments between the ensiling days. We have no explanation for the reduction in the ethanol for untreated HMC between 21 and $90 \mathrm{~d}$. However, treatment with Safesil reduced the concentrations of ethanol when compared with the value found in untreated HMC after both times of ensiling. A reduction in the production of ethanol in corn silages via treatment with potassium sorbate and sodium benzoate was similar to results reported by others (Kleinschmit et al., 2005; Teller et al., 2012) and is likely the direct result of suppression of yeasts.

The number of LAB decreased with days of ensiling and was affected by the treatment with the additive. High-moisture corn treated with Safesil had fewer LAB than the untreated HMC independent of the days of ensiling, although this reduction was not large enough to be reflected in changes in concentrations of organic acids as previously discussed. Numbers of yeasts were relatively low in all fermented samples $(<4 \log \mathrm{cfu} / \mathrm{g})$ and were similar among treatments after $21 \mathrm{~d}$ but lower in Safesil-treated HMC $(<2 \log \mathrm{cfu} / \mathrm{g})$ than in untreated HMC (3.22 log cfu/g) after $90 \mathrm{~d}$ of ensiling. Marked reductions in numbers of yeasts have also been reported in corn silage when it was treated with potassium sorbate (Teller et al., 2012) and sodium benzoate (Da Silva et al., 2014), or both ingredients combined (Auerbach and Nadeau, 2013). The numbers of molds in ensiled HMC were below the lowest dilution $\left(10^{-2}\right)$ used in this study (data not shown).

The DM recovery was consistently improved in all treatments with Safesil when compared with control at both days of ensiling and is most likely a direct result of lower production of ethanol because fermentation of glucose by yeasts results in a marked loss of DM via the production of $\mathrm{CO}_{2}$ (McDonald et al., 1991). Although we have no explanation why the DM recovery was lower (98.12) for d 21 silage compared with d 90 silage (98.78), this difference was extremely small.

Treatment with Safesil markedly improved the aerobic stability (Table 4) of HMC after $21 \mathrm{~d}(89 \mathrm{~h}$ for untreated HMC vs. $>500 \mathrm{~h}$ for HMC treated with Safesil at all levels) and after $90 \mathrm{~d}$ of ensiling (77 h for untreated HMC vs. $>500 \mathrm{~h}$ for HMC treated with Safesil at all levels). These findings were most likely a direct result of inhibition of lactate assimilating yeasts because these organisms are usually the first to start the aerobic deterioration processes of corn silage and HMC in North America. These organisms become active when exposed to air, leading to an increase in silage temperature and the production of $\mathrm{CO}_{2}(\mathrm{Li}$ and Nishino, 2011; Borreani et al., 2013). Degradation of lactic acid causes an increase in the $\mathrm{pH}$, which allows for the development of other groups of microorganisms such as molds and Bacillus (Lindgren et al., 2002; Borreani et al., 2013). The absence of an effect on numbers of yeasts for Safesil treatments compared with untreated HMC at $21 \mathrm{~d}$ does not agree with the reductions in ethanol and the improvement in aerobic stability. However, yeasts could be affected in different ways by the additives. One possibility is that the species of yeasts were changed with adding Safesil, but we used a general agar for total yeasts, not lactate assimilators, and thus could not confirm this possibility. Furthermore, although weak organic acids can be fungicidal, at high concentrations they can also be fungistatic, resulting in slower growth rates (prolonged lag phases of growth) at low concentrations (Neves et al., 1994; Ullah et al., 2012).

The key effect of weak-acid inhibition on the growth of yeasts is usually attributed to the rapid diffusion of undissociated molecules through the plasma membrane. When the $\mathrm{pH}$ is low, the concentration of undissociated acids increases and the dissociation of these acids within the cells liberates protons and acidifies the cytoplasm, disrupting internal cell mechanisms (Lambert and Stratford, 1999).

Antifungal effects of organic acids are also attributed to depletion of ATP required to rid the cell of excess hydrogen from the dissociated acid (Koczoń, 2009). Specifically, benzoic acid has also shown to have inhibitory effects on cell wall metabolism and citrate cycle enzymes (Belitz et al., 2009). Sorbic acid can also inhibit yeasts by altering metabolic processes in their membranes (Stratford and Anslow, 1998). Synergistic effects of combinations of sodium nitrite with either potassium sorbate or sodium benzoate and of potassium sorbate and sodium benzoate have been reported on some fungi and bacteria (Stanojevic et al., 2009), although only one, Candida albicans, of the tested microorganisms has been reported in aerobic deterioration (Pahlow et al., 2003). This suggests that the high effectiveness observed in the present study, even in the lowest dose used, could be due to synergistic effects of those preservatives, as observed by Auerbach and Nadeau (2013), because the amount applied of each ingredient individually, even at the highest dose $(4 \mathrm{~L} / \mathrm{t})$, was lower than that reported in previous studies (Bernardes et al., 2014, Hafner et al., 2014). 


\section{CONCLUSIONS}

The addition of the chemical additive containing sodium benzoate, potassium sorbate, and sodium nitrite reduced the number of yeasts in HMC after $90 \mathrm{~d}$ of ensiling and thus the accumulation of ethanol during silage fermentation. Treatment with all levels of Safesil also resulted in higher DM recovered after ensiling and better stability when HMC was exposed to air. Application of Safesil could be an important tool to help improve the aerobic stability of HMC and recover more DM for feeding.

\section{ACKNOWLEDGMENTS}

Thiago Da Silva was a visiting scholar from the University of Vicosa and was funded by the National Council for Scientific and Technological Development (CNPq, Brazil). This study was partially funded by $\mathrm{Ab}$ Hanson and Möhring, Halmstad, Sweden. The authors thank Bill and Diane Miller of Chesapeake Gold Farms Inc. (Rising Sun, MD) for the high-moisture corn used in this study.

\section{REFERENCES}

Alli, I., S. Pabari, R. Fairbairn, and B. E. Baker. 1985. The effects of sorbates on the ensilage of chopped whole-plant maize and lucerne. J. Sci. Food Agric. 36:63-70.

Alonso, V. A., C. M. Pereyra, L. A. M. Keller, A. M. Dalcero, C. A. R. Rosa, S. M. Chiacchiera, and L. R. Cavaglieri. 2013. Fungi and mycotoxins in silage: An overview. J. Appl. Microbiol. 115:637-643.

Auerbach, H., and E. Nadeau. 2013. Effects of chemical additives on whole crop maize silage traits. Pages $736-737$ in Proc. 22nd Int. Grassland Congress. New South Wales Department of Primary Industry, Kite St., Orange New South Wales, Australia.

Belitz, H. D., W. Grosch, and P. Schieberle. 2009. Food Chemistry. 4th Revised and Extended Edition. Springer-Verlag. Berlin, Germany.

Bernardes, T. F., I. L. Oliveira, M. A. S. Lara, D. R. Casagrande, and O. G. Pereira. 2014. Effects of potassium sorbate and sodium benzoate at two application rates on fermentation and aerobic stability of maize silage. Grass Forage Sci. 68:1-7.

Borreani, G., P. Dolci, E. Tabacco, and L. Cocolin. 2013. Aerobic deterioration stimulates outgrowth of spore-forming Paenibacillus in corn silage stored under oxygen-barrier or polyethylene films. J. Dairy Sci. 96:5206-5216.

Buchanan-Smith, J., T. K. Smith, and J. R. Morris. 2003. High Moisture Grain and By-products. Pages 825-854 in Silage Science and Technology. D. R. Buxton, R. E. Muck, and J. H. Harrison, ed. American Society of Agronomy, Madison, WI.

Canizares, G. I. L., H. C. Goncalves, C. Costa, L. Rodrigues, J. J. L. Menezes, H. F. B. Gomes, R. O. Marques, and R. H. Branco. 2011. Use of high moisture corn silage replacing dry corn on intake, apparent digestibility, production and composition of milk of dairy goats. Rev. Bras. Zootec. 40:860-865.

Da Silva, N. C., J. P. dos Santos, C. L. S. Avila, A. R. Evangelista, D. R. Casagrande, and T. F. Bernardes. 2014. Evaluation of the effects of two Lactobacillus buchneri strains and sodium benzoate on the characteristics of corn silage in a hot-climate environment. Grassland Sci. 60:169-177.

Dairy One. 2015. Interactive Feed Composition Library for Corn Silage. 5/1/2000 to 4/30/2014. Accessed Jan. 15, 2015. http://dairyone. com/analytical-services/feed-and-forage/feed-compositionlibrary/interactive-feed-composition-library/.

Diaz, E., D. R. Ouellet, A. Amyot, R. Berthiaume, and M. C. Thivierge. 2013. Effect of inoculated or ammoniated high-moisture ear corn on finishing performance of steers. Anim. Feed Sci. Technol. 182:25-32.

Ensley, S., and S. K. Barnhart. 2012. Nitrate toxicity. Publ. No. IBC50. Iowa State University, Ames.

Ferraretto, L. F., K. Taysom, D. M. Taysom, D. R. Shaver, and P. C. Hoffman. 2014. Relationships between dry matter content, ensiling, ammonia-nitrogen, and ruminal in vitro starch digestibility in high-moisture corn samples. J. Dairy Sci. 97:3221-3227.

Gerlach, K., F. Roß, K. Weiß, W. Buscher, and K. H. Sudekum. 2013. Changes in maize silage fermentation products during aerobic deterioration and its impact on feed intake by goats. Agric. Food Sci. $22: 168-181$.

Goering, H. K., and P. J. Van Soest. 1970. Forage Fiber Analyses (Apparatus, Reagents, Procedures, and Some Applications). Agric Handbook. No 379. ARS-USDA, Washington, DC.

Hafner, S. D. R. B. Franco, L. Kung Jr., C. A. Rotz, and F. Mitloehner. 2014. Potassium sorbate reduces production of ethanol and 2 esters in corn silage. J. Dairy Sci. 97:7870-7878.

Hall, M. B. 2009. Analysis of starch, including maltooligosaccharides in animal feeds: Comparison of methods and a recommended method for AOAC Collaborative Study. J. AOAC Int. 92:42-49.

Hoffman, P. C., N. M. Esser, R. D. Shaver, W. K. Coblentz, M. P. Scott, and A. L. Bodnar. 2011. Influence of ensiling time and inoculation on alteration of the starch-protein matrix in high-moisture corn. J. Dairy Sci. 94:2465-2474.

Hoffman, P. C., and S. M. Ocker. 1997. Quantification of milk yield losses associated with feeding aerobically unstable high moisture corn. J. Dairy Sci. 80(Suppl. 1):234. (Abstr.)

Ivanek, R., Y. Gröhn, and M. Wiedmann. 2006. Listeria monocytogenes in multiple habitats and host populations: Review of available data for mathematical modeling. Foodborne Pathog. Dis. 3:319-336

Jobim, C. C., L. G. Nussio, R. A. Reis, and P. Schmidt. 2007. Methodological advances in evaluation of preserved forage quality. Braz. J. Anim. Sci. 36:101-119. (In Portuguese, English abstract)

Kleinschmit, D. H., R. J. Schmidt, and L. Kung Jr.. 2005. The effects of various antifungal additives on the fermentation and aerobic stability of corn silage. J. Dairy Sci. 88:2130-2139.

Knický, M., and R. Spörndly. 2009. Sodium benzoate, potassium sorbate, and sodium nitrate as silage additives. J. Sci. Food Agric. 89:2659-2667.

Knický, M., and R. Spörndly. 2011. The ensiling capability of a mixture of sodium benzoate, potassium sorbate, and sodium nitrite. J. Dairy Sci. 94:824-831.

Koczoń, P. 2009. Growth inhibition mode of action of selected benzoic acid derivatives against the yeast Pichia anomala. J. Food Prot. 72:791-800.

Krishnamoorthy, U., T. V. Muscato, C. J. Sniffen, and P. J. Van Soest. 1982. Borate phosphate procedure as detailed in nitrogen fractions in selected feedstuffs. J. Dairy Sci. 65:217-225.

Kung, L. Jr., C. L. Meyers, J. M. Neylon, C. C. Taylor, J. A. Lazartic, J. A. Mills, and A. G. Whiter. 2004. The effects of buffered propionic acid-based additives alone or combined with microbial inoculation on the fermentation of high moisture corn and wholecrop barley. J. Dairy Sci. 87:1310-1316.

Lambert, R. J., and M. Stratford. 1999. Weak acid preservatives: Modeling microbial inhibition and response. J. Appl. Microbiol. $86: 157-164$.

Li, Y., and N. Nishino. 2011. Bacterial and fungal communities of wilted Italian ryegrass silage inoculated with and without Lactobacillus rhamnosus or Lactobacillus buchneri. Lett. Appl. Microbiol. $52: 314-321$.

Lindgren, S., G. Pahlow, and E. Oldenburg. 2002. Influence of microbes and their metabolites on feed and food quality. Multi-Function Grasslands. J. L. Durand, J. C. Emile, C. Huyghe, and G. Lemaire, ed. Pages 503-511 in Proc. 19th General Meeting of the European Grassland Federation, La Rochelle, France. 
Loučka, R. 2010. Stability of high moisture maize grain ensiled with and without chemical additives. Res. Pig Breeding. 4:5-8.

McDonald, P., A. R. Henderson, and S. J. E. Heron. 1991. The Biochemistry of Silage. 2nd edition. Chalcombe Publications, Marlow, UK.

Muck, R. E., and J. T. Dickerson. 1988. Storage temperature effects on proteolysis in alfalfa silage. Trans. ASAE 31:1005-1009.

Nelson, N. 1944. A photometric adaptation of the Somogyi method for the determination of glucose. J. Biol. Chem. 153:375-380.

Neves, L., M. E. Pampulha, and M. C. Loureiro-Dias. 1994. Resistance of food spoilage yeasts to sorbic acid. Lett. Appl. Microbiol. 19:8-11.

Pahlow, G., R. E. Muck, F. Driehuis, and S. J. W. H. Oude Elferink. 2003. Microbiology of ensiling. Page 50 in Silage Science and Technology. D. R. Buxton, R. E. Muck, and J. H. Harrison, ed. Am. Soc. Agron., Madison, WI.

Playne, M. J., and P. McDonald. 1966. The buffering constituents of herbage and of silage. J. Sci. Food Agric. 17:264-268.

Reddy, D., J. R. Lancaster, and D. P. Cormforth. 1983. Nitrite inhibition of Clostridium botulinum: Electron spin resonance detection of iron-nitric oxide complexes. Science 221:769-770.

Schmidt, R. J., W. Hu, J. A. Mills, and L. Kung Jr.. 2009. The development of lactic acid bacteria and Lactobacillus buchneri and their effects on the fermentation of alfalfa silage. J. Dairy Sci. 92:5005-5010.

Sebastian, S., L. E. Phillip, V. Fellner, and E. S. Idziak. 1996. Comparative assessment of bacterial inoculation and propionic acid treatment on aerobic stability and microbial populations of ensiled high-moisture ear corn. J. Anim. Sci. 74:447-456.

Snedecor, G. W., and W. G. Cochran. 1980. Statistical Methods. 6th ed. Iowa State Univ. Press, Ames.

Stanojevic, D., L. Comic, O. Stefanovic, and S. Solujic-Sukdolak. 2009. Antimicrobial effects of sodium benzoate, sodium nitrite and potassium sorbate and their synergistic action in vitro. Bulg. J. Agric. Sci. 15:307-311.

Stratford, M., and P. A. Anslow. 1998. Evidence that sorbic acid does not inhibit yeast as a classic 'weak acid preservative'. Lett. Appl. Microbiol. 27:203-206.
Szasz, J. I., C. W. Hunt, P. A. Szasz, R. A. Weber, F. N. Owens, W Kezar, and O. A. Turgeon. 2007. Influence of endosperm vitreousness and kernel moisture at harvest on site and extent of digestion of high-moisture corn by feedlot steers. J. Anim. Sci. 85:2214-2221.

Taylor, C. C., and L. Kung Jr.. 2002. The effect of Lactobacillus buchneri 40788 on the fermentation and aerobic stability of high moisture corn in laboratory silos. J. Dairy Sci. 85:1526-1532.

Tecator. 1992. Tecator nitrate (cadmium reduction method). Application note-ASN 110-01/92. Tecator, Höganäs, Sweden.

Teller, R. S., R. J. Schmidt, L. W. Whitlow, and L. Kung Jr.. 2012. Effect of physical damage to ears of corn before harvest and treatment with various additives on the concentration of mycotoxins, silage fermentation, and aerobic stability of corn silage. J. Dairy Sci. 95:1428-1436.

Ullah, A., R. Orij, S. Brul, and G. J. Smits. 2012. Quantitative analysis of the modes of growth inhibition by weak organic acids in Saccharomyces cerevisiae. Appl. Environ. Microbiol. 78:8377-8387.

Van Soest, P. J., J. B. Robertson, and B. A. Lewis. 1991. Methods for dietary fiber, neutral detergent fiber, and nonstarch polysaccharides in relation to animal nutrition. J. Dairy Sci. 74:3583-3597.

Weatherburn, M. W. 1967. Phenol-hypochlorite reaction for determinations of ammonia. Anal. Chem. 39:971-974.

Whitlock, L. A., T. J. Wistuba, M. K. Seifers, R. V. Pope, and K. K. Bolsen. 2000. Effect of level of surface-spoiled silage on the nutritive value of corn silage diets. J. Dairy Sci. 83(Suppl. 1):110. (Abstr.)

Woods, L. F. J., J. M. Wood, and P. A. Gibbs. 1981. The involvement of nitric oxide in the inhibition of phosphoroclastic system in Clostridium sporogenes by sodium nitrite. J. Gen. Microbiol. 125:399-406.

Yasin, M., M. A. Hanna, and L. B. Bullerman. 1992. Potassium sorbate inhibition of mold in high moisture corn. Trans. ASAE $35: 1229-1233$ 